\section{Re: Psykiaterrollen i krise}

Takk til professor Vaglum for en flott artikkel (1). Som barnepsykiater lever jeg i dette dilemmaet daglig. Da jeg begynte i barneog ungdomspsykiatrien for fem år siden, ble jeg forbauset og oppgitt over hvordan medisinering og somatisk oppfølging ble håndtert. Dette er noe vi diskuterer og frustreres over i kollegagruppen og på grunnkurs. Som snill konformist og straks spesialist, tenker jeg at hver og en må gjøre det beste ut av situasjonen, og under veiledning og sammen med kollegaer finne sin vei. Dette er en kjempeutfordring.

Legene må være klar over at for hver eneste pasient man er involvert i, må man kunne svare fullt ut for sin innblanding, i dag og om ti år. Hver og en må sette press på ledere og system der det byr seg. Her i Stavanger har vi et relativt stort gjennomtrekk av unge leger i barne- og ungdomspsykiatrien, og barn og unge må forholde seg til mange leger som «harelabber» over dem. Jeg har truffet tiåringer som sier: «Hvorfor skal jeg snakke med deg? Du er den tredje legen jeg treffer bare i år!»

I den store gruppen barn som behandles for $\mathrm{AD} / \mathrm{HD}$, er den biopsykososiale modellen svært viktig. Jeg opplever at disse barna ofte medisineres på svakt grunnlag, og oppfølgingen blir sporadisk. At fastlegen skal følge disse barna og familiene, blir ofte en utilstrekkelig løsning i praksis. Det er et ekstra stort ansvar å medisinere barn med psykofarmaka gjennom oppvekst og modning - et ansvar barne- og ungdomspsykiatrien ikke håndterer godt nok med dagens legedekning. Så takk til Vaglum for initiativ til debatt og endring!

Christoffer Annerstedt

Christoffer.annerstedt@gmail.com

Christoffer Annerstedt (f. 1976) er lege på Barne- og ungdomspsykiatrisk avdeling, Stavanger universitetssykehus.

Ingen oppgitte interessekonflikter.

Litteratur

1. Vaglum P. Psykiaterrollen i krise. Tidsskr Nor Legeforen 2014; 134: 1221.

\section{Re: Renal sympatisk denervering ved terapiresistent hypertensjon}

Tidsskriftet nr 12014 omtalte vi renal denervering (RDN) ved terapiresistent hypertensjon i en oversiktsartikkel (1). I etterkant har det tilkommet nye studier som ikke viser ønsket effekt av RDN, som vi kort ønsker å oppsummere her.

En studie av 109 pasienter med terapiresistent hypertensjon ble publisert i Lancet for få år siden (2), og den antydet en blodtrykkssenkende effekt av RDN på opptil 32/16 mmHg etter seks måneder. Det tekniske utstyret fikk CE-godkjennelse, og produsenten(e) markedsførte utstyr (ablasjonskatetre) til bruk - også i norske sykehus og på norske pasienter. I Tyskland har 200 sentra utført RDN de siste årene, og i Sveits, Sverige og Nederland har det offentlige refundert utgifter på 7-8.000 Euro per pasient. Opptil 20.000 pasienter har fått gjennomført RDN på verdensbasis.

Flere avdelinger ved Oslo universitetssykehus Ullevål har samarbeidet om RDN ved terapiresistent hypertensjon i en forskningsprotokoll (1). Pasienter med sekundær- og kontorhypertensjon ble ikke inkludert. Før inklusjon måtte pasientene kvalifisere seg med bevitnet inntak av alle blodtrykksenkende medisiner umiddelbart før ambulatorisk blodtrykksmåling. I vår første serie kvalifiserte seks pasienter av de 18 som ble utredet, og blodtrykket var uendret etter RDN (3). I vår andre serie ble 19 pasienter (av 65 henviste) randomisert til henholdsvis RDN vs. forbedring av den medikamentelle behandlingen basert på hemodynamiske målinger (4). I RDN-gruppen var det et mindre fall i kontor- og ambulatorisk blodtrykk etter tre og seks måneder, noe vi tror kan tilskrives placebo, regresjon til middelverdien eller Hawthorneeffekt. Blod- trykket normaliserte seg hos nesten alle i medikamentgruppen, der endringene i hovedsak var økt diuretikadose og mindre betablokkerbehandling. Studien er også kort omtalt av Kari Tveito i Tidsskriftet nr 12/13 2014 (5).

En stor prospektiv, randomisert og sham-kontrollert amerikansk studie som nylig ble publisert, viste omtrent det samme fallet i blodtrykk i både RDN og sham-kontroll gruppen, dvs. ingen sikker blodtrykkssenkende effekt av RDN (6). RDN er derfor ikke «evidencebased medicine» og bør ikke utføres utenfor forskningsprotokoller.

Sverre E. Kjeldsen
sverrkj@online.no
Heidi Sørensen
Fadl Elmula Mohamed Fadl Elmula
Magne Brekke
Eyvind Gjønnæss
Ulla Hjørnholm
Vibeke N. Kjære
Morten Rostrup
Eigil Fossum
Ingrid Os
Aud Stenehjem
Aud Høieggen
Pavel Hoffmann

Sverre E. Kjeldsen (f. 1953) er dr.med., spesialist i indremedisin og i hjertesykdommer og professor og overlege ved Avdeling for kardiologi, medisinsk klinikk, Oslo universitetssykehus, Ullevål, og Institutt for klinisk medisin ved Universitetet i Oslo.

Interessekonflikter: Han har mottatt konsulenthonorar/foredragshonorar fra Medtronic, Bayer, Takeda, Serodus, AstraZeneca, Pronova, Merck, Novartis, Hemo Sahpiens.

Heidi Sørensen (f. 1989) er medisinstudent ved Det medisinske fakultet ved Universitetet i Oslo.

Ingen oppgitte interessekonflikter.

Fadl Elmula Mohamed Fadl Elmula (f. 1972) er spesialist i indremedisin og i hjertesykdommer og stipendiat ved avdeling for generell indremedisin, medisinsk klinikk, Oslo universitetssykehus, Ullevål og Institutt for klinisk medisin ved Universitetet i Oslo.

Interessekonflikter: Han har mottatt reisestøtte og foredragshonorar fra Medtronic.

Magne Brekke (f. 1955) er spesialist i radiologi og leder av Angiografiog intervensjonsenheten, Oslo universitetssykehus, Ullevål.

Ingen oppgitte interessekonflikter.

Eyvind Gjønnæss (f. 1966) er spesialist i radiologi og overlege ved Kardiologisk avdeling, Feiringklinikken.

Ingen oppgitte interessekonflikter.

Ulla Hjørnholm (f. 1971) er sykepleier og studiekoordinator ved Seksjon for indremedisinsk forskning, Medisinsk klinikk, Oslo universitetssykehus, Ullevål.

Ingen oppgitte interessekonflikter.

Vibeke Norheim Kjær (f. 1959) er bioingeniør ved Seksjon for indremedisinsk forskning, Medisinsk klinikk, Oslo universitetssykehus, Ullevål. Ingen oppgitte interessekonflikter.

Morten Rostrup (f. 1958) er dr.med., spesialist i indremedisin og overlege ved Avdeling for akuttmedisin, Medisinsk klinikk, Oslo universitetssykehus, Ullevål.

Ingen oppgitte interessekonflikter.

Eigil Fossum (f. 1962) er dr.med. og spesialist i indremedisin og i hjertesykdommer og overlege ved seksjon for intervensjonskardiologi, Avdeling for kardiologi, Hjerte-, lunge- og karklinikken ved Oslo universitetssykehus, Ullevål.

Ingen oppgitte interessekonflikter. 
Ingrid Os (f. 1950) er dr. med., spesialist i indremedisin og i nyresykdommer, professor i nyremedisin, overlege/seksjonsleder ved Nyremedisinsk avdeling, Medisinsk klinikk, Oslo universitetssykehus, Ullevål, og studiedekan ved det medisinske fakultet, Universitetet i Oslo.

Ingen oppgitte interessekonflikter.

Aud Stenehjem (f. 1957) er ph.d., spesialist i fysikalsk medisin og rehabilitering, i indremedisin og i nyresykdommer og avdelingsleder ved Nyremedisinsk avdeling, Medisinsk klinikk, Oslo universitetssykehus, Ullevål. Interessekonflikter: Hun er medlem av vitenskapelig rådgivningsgruppe hos Baxter.

Aud Høieggen (f. 1956) er dr.med., spesialist i indremedisin og i nyresykdommer, overlege og førsteamanuensis ved Nyremedisinsk avdeling, Medisinsk klinikk ved Oslo universitetssykehus, Ullevål.

Interessekonflikter: Hun har mottatt foredragshonorar fra Amgen, St. Jude, Novartis, AstraZeneca.

Pavel Hoffmann (f. 1958) er dr.med. i fysiologi, spesialist i radiologi og overlege ved Seksjon for intervensjonskardiologi, Avdeling for kardiologi, Hjerte-, lunge- og karklinikken ved Oslo universitetssykehus, Ullevål. Interessekonflikter: Han har mottatt reisestøtte fra Medtronic.

\section{Litteratur}

1. Sorensen H, Fadl Elmula FE, Kjeldsen SE et al. Renal sympatisk denervering ved terapiresistent hypertensjon Tidsskr Nor Legeforen 2014: 134: 32-6.

2. Esler MD, Krum H, Sobotka PA et al. Renal sympathetic denervation in patients with treatment-resistant hypertension (The Symplicity HTN-2 Trial): a randomised controlled trial. Lancet 2010; 376: 1903-9

3. Fadl Elmula FE, Hoffmann P. Fossum E et al. Renal sympathetic denervation in patients with treatment-resistant hypertension after witnessed intake of medication before qualifying ambulatory blood pressure. Hypertension 2013; 62: $526-32$.

4. Fadl Elmula FE, Hoffmann P, Larstorp AC et al. Adjusted drug treatment is superior to renal sympathetic denervation in patients with true treatment-resistant hypertension. Hypertension 2014; 63: $991-9$

5. Tveito K. Justering av legemidler er bedre enn renal denervering. Tidsskr Nor Legeforen 2014; 134: 1001

6. Bhatt DL, Kandzari DE, O'Neill WW et al. A controlled trial of renal denervation for resistant hypertension. N Engl J Med 2014; 370: 1393-401.

\section{Re: Trenger vi eksamen?}

Å studere medisin er frustrerende. Dette vitnes i kommentarartikkelen til Næss (1), og sånn har det alltid vært. Studenter skal tenke kritisk og tvile på det som er sagt, samtidig som de skal være kreative og se alternativer. På universitetet lærer man for livet og ikke for å bestå en eksamen. Pensumet er stort, og man blir nødt til å sile det som er viktigst fra det som er mindre viktig. Dette kan være en frustrerende prosess, især når eksamen nærmer seg.

Det er så utrolig mye man ikke vet, og med økt viten dukker det stadig opp flere spørsmål, og mindre og mindre vet man sikkert. Medisinsk viten endrer seg fort, og derfor blir mye av det man har lært utdatert. Under min studietid var det forbudt å anvende betablokker hos pasienter med hjertesvikt. Året før jeg ble turnuslege ble denne kunnskapen avkreftet, og i dag er hjertesvikt indikasjon nummer én for betablokker (2). Det samme gjelder adrenalin i lokalbedøvelse til fingre og tær (3). Litteraturen stemmer ikke allid overens med virkeligheten. Prøvene bestod jeg fordi jeg lærte leksene, men ikke fordi alt som jeg lærte var riktig. Endringene har jeg fått med meg fordi jeg fortsetter å lære og leser like mye som før. Du som studerer medisin: Vær forberedt på livslang oppdatering og daglig prøve.

Jeg tror Næss har rett, eksamens betydning for læring er begrenset, men avholdt på riktig vis avslører den hvem som kan og hvem som ikke kan. Kanskje bør vi supplere eksaminasjonen med nærmere observasjon, og stille krav om attester av overordnede for å komme videre i studiet, og kanskje spesielt i spesialistutdannelsen?

Kunnskap og viten er et privilegium, og med å studere medisin følger et ansvar: $\AA$ innhente og formidle viten videre til neste generasjon. Vår plikt er å sikre optimal utdannelse og rekruttere kompetente fremtidige kollegaer - kollegaer som Næss som ikke er redd for å stille spørsmål og kritisere vanesaker. Prøvene kommer vi ikke utenom, og hvis vi er heldige stilles det større krav i fremtiden og strengere prøver blir avholdt $i$ tråd med en mer målrettet utdannelse av leger og legespesialister.

\section{Gudjon Leifur Gunnarsson}

gudjonleifur@yahoo.com

Gudjon Leifur Gunnarsson (f. 1973) er overlege i plastikkirurgi ved Sykehuset Telemark Skien.

Ingen oppgitte interessekonflikter.

Litteratur

1. Næss T. Trenger vi eksamen? Tidsskr Nor Legeforen 2014; e-publisert 23.6.2014.

2. Lechat $P$, Packer $M$, Chalon $S$ et al. Clinical effects of beta-adrenergic blockade in chronic heart failure: a meta-analysis of double-blind, placebo-controlled, randomized trials. Circulation 1998; 98: 1184-91.

3. Denkler K. A comprehensive review of epinephrine in the finger: to do or not to do. Plast Reconstr Surg 2001; 108: 114-24 